\title{
Insomni og risiko for hjerte- og karsykdom
}

\author{
Søvnplager spiller en viktig rolle for hjertehelse og bør tas med i vur- \\ deringen ved forebygging av hjerte- og karsykdom.
}

Nyere forskning taler for at dårlig søvnkvalitet bidrar til utvikling av hjerte- og karsykdom. Insomni er en opplevelse av å ha problemer med innsoving, for tidlig oppvåkning eller dårlig søvnkvalitet og er den vanligste form for søvnforstyrrelse.

- Forekomsten av minst ett av symptomene kan være så høy som $33 \%$ i den generelle befolkningen. Det er få studier av sammenhengen mellom insomni og risiko for hjerte- og karsykdom. Insomni er forbundet med høyere blodtrykk og kolesterol samt høyere kroppsmasseindeks enn hos personer uten slike søvnplager, forteller Lars Erik Laugsand.

Hans avhandling baserer seg på den andre Helseundersøkelsen i Nord-Trøndelag, som foregikk i perioden 1995-97. Alle personer i fylket over 20 år ble invitert, og deltakerne fylte ut spørreskjema, gjennomgikk en klinisk undersøkelse og ble tatt blodprøver av. I spørreskjemaet ble det spurt om søvnpla- ger. Frem til og med 2008 ble det fortløpende registrert førstegangs hjerteinfarkt eller hjertesvikt.

- Resultatene våre viser at personer med symptomer på insomni hadde en moderat økt risiko for førstegangs hjerteinfarkt og hjertesvikt sammenliknet med de uten søvnproblemer. Flere symptomer på insomni ga høyere risiko. Vi justerte for forskjeller som alder, kjønn, utdanningsnivå, blodtrykk, kolesterol, diabetes, vekt, fysisk aktivitet og røyking og tok høyde for symptomer på depresjon og angst. Våre analyser viste at disse mulig konfunderende faktorene ikke påvirket resultatene, noe som styrker sannsynligheten for at våre funn har en underliggende biologisk årsak, avslutter Laugsand.

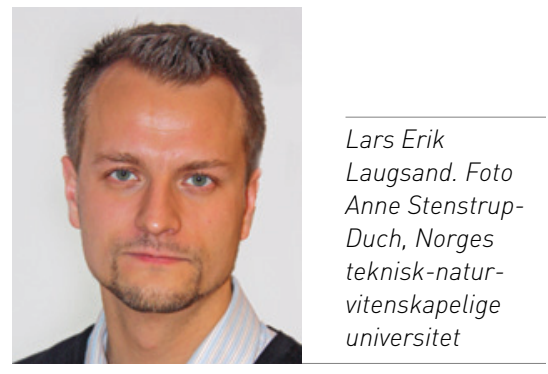

Ingrid Skinlo Rokstad

ingrid.rokstad@legeforeningen.no

Tidsskriftet

\section{Disputas}

Lars Erik Laugsand disputerte for ph.d.-graden ved Norges teknisk-naturvitenskapelige universitet 24.8. 2012. Tittelen på avhandlingen er Insomni og risiko for hjerte- og karsykdom.

\section{Fritt sykehusvalg under lupen}

\section{Ventetiden kan bli kortere hvis man ikke velger lokalsykehuset. Syke- husene kan få flere elektive pasienter hvis kommunikasjonen mellom dem og fastlegene blir bedre.}

Pasientrettighetsloven trådte i kraft 1.1. 2001. Med den kom «fritt sykehusvalg-reformen»: Somatiske pasienter fikk rett til å velge sykehus for undersøkelse og behandling, og sykehuset kan være lokalisert hvor som helst $i$ landet. Ordningen er senere utvidet til å omfatte psykiatri og rusbehandling. Ånen Ringards avhandling er et bidrag til evalueringen av ordningen.

- Målet har vært å undersøke virkningen av reformen: Se på fastlegenes rolle og hva som er årsaken når de henviser pasienten til et annet sykehus enn lokalsykehuset. Dessuten ønsket vi å finne ut hvilke pasienter som benytter seg av ordningen og om disse oppnår kortere ventetider, sier Ringard.

Avhandlingen bygger på data fra Norsk pasientregister (NPR), et spørreskjema sendt til fastleger og ett til utvalgte pasienter ved 20 sykehus, både pasienter som var og ikke var blitt behandlet ved lokalsykehuset.

\section{Anne Forus}

anne.forus@hotmail.com

Tidsskriftet
- Det ser ut til pasienter med høy utdanning oftere benytter ordningen med fritt sykehusvalg enn pasienter med lav utdanning. Når pasienten først har valgt, viser det seg at det å velge et annet sykehus enn lokalsykehuset gir kortere ventetid.

Formelle koordineringsmekanismer mellom sykehus og fastlege reduserte sjansene for at fastlegen henviste til et annet sykehus enn lokalsykehuset. Hvis det var lang avstand til lokalsykehuset, og lang ventetid, var det større sjanse for at fastlegen henviste pasienten til et annet sykehus, sier Ringard.

- Sykehusene kan, om de ønsker det, altså tiltrekke seg flere elektive pasienter ved å utvikle arenaer for kommunikasjon og samarbeid med fastlegene, sier han.

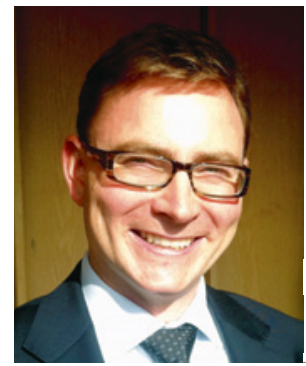

Ånen Ringard. Foto Marie Brudvik

\section{Disputas}

Ånen Ringard disputerte for ph.d.-graden ved Universitetet i Oslo 14.9. 2012. Tittelen på avhandlingen er Choice of hospital - four essays on the 2001 Norwegian Hospital Choice Reform. 